Turkey and Europeanization of Foreign Policy?

Author(s): TARIK OĞUZLU

Source: Political Science Quarterly, Vol. 125, No. 4 (Winter 2010-11), pp. 657-683

Published by: The Academy of Political Science

Stable URL: http://www.jstor.org/stable/25767094

Accessed: 16-10-2017 11:22 UTC

\title{
REFERENCES
}

Linked references are available on JSTOR for this article:

http://www.jstor.org/stable/25767094?seq=1\&cid=pdf-reference\#references_tab_contents You may need to $\log$ in to JSTOR to access the linked references.

JSTOR is a not-for-profit service that helps scholars, researchers, and students discover, use, and build upon a wide range of content in a trusted digital archive. We use information technology and tools to increase productivity and facilitate new forms of scholarship. For more information about JSTOR, please contact support@jstor.org.

Your use of the JSTOR archive indicates your acceptance of the Terms \& Conditions of Use, available at http://about.jstor.org/terms

The Academy of Political Science is collaborating with JSTOR to digitize, preserve and extend access to Political Science Quarterly 


\section{Turkey and Europeanization of Foreign Policy?}

TARIK OĞUZLU

Many commentators have recently argued that the confirmation of Turkey's European Union (EU) membership candidacy status in December 1999 and the initiation of the formal accession negotiations in October 2005 have accelerated the Europeanization of Turkish foreign policy (henceforth true Europeanization). ${ }^{1}$ The most appropriate example mentioned in this regard is Turkey's refusal to cooperate with the United States on the eve of the war in Iraq in March 2003. The absence of EU support (particularly the GermanFrench axis) for the American war aims in Iraq was considered to have been one of the factors causing Turkey's reluctance to take part in the war. In a similar vein, Turkey's about-face in the Cyprus dispute has been attributed to the growing Turkish penchant for EU membership under the reign of the Justice and Development Party (henceforth AKP). The AKP leadership was assumed to have believed that the faster the Cyprus dispute was resolved, the greater would be the chances of Turkey's accession to the European Union. ${ }^{2}$

Analysts also point to Turkey's changing approach toward the Kurds of northern Iraq in recent years to demonstrate true Europeanization. The claim here is that Turkey's "realist exclusionist" approach toward Iraqi Kurds has gradually turned out to be "liberal integrationist," alongside the EU accession

\footnotetext{
${ }^{1}$ Eleni Lazarou, "A European State in the Making? Europeanization and Turkish Foreign Policy" (Hellenic Center for European Studies policy paper [EKEM]), 2006, accessed at http://www.ekem.gr/ archives/2006/11/a_european_stat.html, 3 January 2009; Serhat Güvenç and Oya Memişoğlu, "Turkey and the Regional Security," in R. Griffits and D. Özdemir, eds., "Turkey and the EU Enlargement: Process of Incorporation (Istanbul: Istanbul Bilgi University Press, 2004), 215-230. Mustafa Aydın and Sinem Açkmeşe, "Europeanization through EU Conditionality: Understanding the New Era in Turkish Foreign Policy," Journal of Southern Europe and the Balkans 9 (December 2007): 262-274.

2 "R.T. Erdoğan, "Kıbrıs'ta Taşlar Oynadı" Voice of America, 25 April 2004, accessed at http:// www.voanews.com/turkish/archive/2004-04/a-2004-04-25-4-1.cfm, 30 January 2009.
}

TARIK OĞUZLU is an associate professor of international relations at Bilkent University. He writes on Turkish foreign policy and the European Union. His articles have been published in leading journals. 
process. Turkey was assumed to have believed that if Ankara treated Iraq and Iraqi Kurds as friends and through liberal eyes, Turkey would be seen as more European by the EU and the chances of its accession to the EU would increase. ${ }^{3}$

Other observers note that Turkish foreign policy has recently become more multilateral and soft-power-oriented in the image of the European Union. The decision-making process in the foreign policy realm has also become more "civilianized," as Turkey undertook reforms in the structure of the National Security Council and as the salience of civil society organizations in public discussions on particular foreign policy issues has increased. ${ }^{4}$

What such observations share in common is the assumption that these changes reflect the improving dynamics of Turkey's EU membership process and the growing determination on the part of Turkish foreign policy elites to join the European Union. Stated somewhat differently, true Europeanization owes its existence to the nationwide consensus that the adoption of the EU's foreign policy understanding and norms would be legitimate and appropriate on the way to Brussels.

This article contends that Turkey's gradual adoption of EU foreign policy norms and practices is not the same thing as the Europeanization of Turkish foreign policy. Rather, this process should be defined as Turkey's Europeanizing foreign policy (henceforth apparent Europeanization). In this sense, this article makes a differentiation between apparent Europeanization and true Europeanization. The former is Europeanization of foreign policy as effect/by-product, whereas the latter is Europeanization of foreign policy as cause. The Turkish case offers a clear example of the first. It is certain that Turkey's foreign policy has appeared European in recent years in terms of style, process, and outcomes; yet this should not be seen as true Europeanization, because this has not been caused by the dynamics of the EU accession process and Turkey's ideational commitment to EU membership. That said, this article equally probes into the reasons why Turkey's Europeanizing foreign policy has not been negatively affected by the change of government from mainstream political parties to the AKP in 2002 as well as the rise of Euro-skeptic feelings across the political spectrum. The main argument is that realpolitik security considerations to counterbalance the United States and Iran, mitigating the negative consequences of the growing instability in the Middle East on national security interests, and the political motivations of the AKP, better account for the apparent Europeanization in the post-September 11 era. Even if Turkey had not been pursuing the goal of membership in the EU, this process would have continued.

\footnotetext{
${ }^{3}$ David L. Phillips, “Turkey's Iraq Problem,” The Boston Globe, 11 January 2007, accessed at http://www.boston.com/news/globe/editorial_opinion/oped/articles/2007/11/01/turkeys_iraq_problem/, 25 January 2009.

${ }^{4}$ Şule Toktaş and Ümit Kurt, The Impact of EU Reform Process on Civil-Military Relations in Turkey, SETA Policy Brief, No. 26, November 2008, accessed at http://www.setav.org/index.php? option $=$ com_content\&task $=$ view\&id $=631 \&$ Itemid $=68,10$ January 2009.
} 
This is not to say that the dynamics of the EU accession process has not played a role in this development. The demands on the part of the EU that Turkey harmonize the main tenets of its foreign policy understanding and practices with those of the EU, should it aspire to become a member, might have engendered some institutional reforms. However, the EU membership process has had limited impact on this development.

Against such a background, the first part of the article will offer a conceptual/theoretical discussion of the terms mentioned above. The goal is to help elucidate the differences between apparent Europeanization and true Europeanization. Then the article will offer an empirical analysis with a view to demonstrating the growing degree of apparent Europeanization in terms of style, process, and outcome dimensions. The following section will simply try to explain this outcome on the basis of non-EU-related factors, such as realpolitik-based security variables and the pragmatic approach of AKP-led Turkey to the EU. The main conclusion this article reaches is that the apparent Europeanization has lately become more an issue of strategic choice than an ideational requirement.

\section{Europeanization as Effect: Apparent Europeanization}

Here one is talking about the possibility that foreign policy norms and understanding of a particular country resemble the foreign policy understanding within the EU area. This might occur in terms of style, process, and outcome. Despite the fact that countries in different parts of the globe might adopt similar foreign policy practices and norms, there is a tendency in the literature to equate them with the EU.

What motivates apparent Europeanization has nothing to do with ideational commitments. The dynamics of the accession/integration process might lead foreign policymakers to adopt some norms and practices of the EU's foreign policy. However, for the dynamics of the accession process to produce such an outcome in the absence of strong ideational commitment to membership, some other variables are needed. These might be other foreign policy concerns, pragmatic calculations, realpolitik security considerations, systemic factors, and dynamics of internal politics. Stated somewhat differently, countries would adopt EU foreign policy norms and practices so long as they believe that this would be in their interest. Here one talks about Europeanization in terms of a dependent variable, but not in terms of an independent variable. Here, it is the logic of consequentiality/instrumentality, rather than the logic of appropriateness, that shapes foreign policy choices of countries. This logic can apply equally to member and candidate countries.

Insights of rationalist institutionalism are useful in this context. Rationalist institutionalism defines Europeanization as states' adaptation to EU foreign and security policy norms on the basis of strategic/instrumental concerns. Here, preferences are previously defined and remain unchanged. According to this 
perspective, politics is seen as aggregating individual preferences into collective action by bargaining, negotiation, coalition formation, and exchange. Society is constituted of individuals for the fulfillment of individual ends. ${ }^{5}$ This approach simply holds that states try to achieve their foreign policy interests by utilizing all possible means at their disposal. ${ }^{6}$ Convergence with European Union norms results from the logic of consequentiality, prioritizing cost-benefit calculations on the part of candidate countries. ${ }^{7}$ Here, what exists is a pragmatic calculation with respect to the benefits of adopting a Europeanizing foreign policy. Aspirant countries adopt an instrumental perspective in the sense that as long as appearing (acting) European serves their previously defined foreign policy interests, they go for it. Looking at it from this theoretical angle, Turkey's convergence with EU foreign policy norms and priorities should not be interpreted as evidence of its intention to help prove its European identity.

\section{Style}

This suggests that countries prefer to pursue their foreign policy interests in regional and multilateral settings and adopt civilian/economic instruments in achieving them. ${ }^{8}$ Threat or use of brute force in foreign policy is regarded as an inappropriate course of action, unless it is seen as a last resort. Even if countries had hard-power resources at their disposal, they would take utmost care to clothe their actions with international legitimacy. Adopting unilateral strategies of coercion, co-opting and coaxing with a view to imposing one's will on others is superseded by the idea that one's ability to shape others' decisions should emanate from the legitimacy of identity and interests in the eyes of others. Put simply, a state that adopts Europeanized foreign policy style would pay more attention to soft power than to hard power. ${ }^{9}$

Moreover, such a state also tries to contribute to the emergence of EU-like regional security complexes in its own environment through civilian diplomacy, international law, multilateralism, and regional institutions..$^{10}$ Diplomatic,

\footnotetext{
${ }^{5}$ James G. March and Johan P. Olsen, "The Institutional Dynamics of International Political Orders," International Organization 52 (Autumn 1998): 943-969, at 949-950.

${ }^{6}$ Reuben Wong, "The Europeanization of Foreign Policy," in Christopher Hill and Michael Smith, eds., International Relations and the European Union (Oxford/New York: Oxford University Press, 2005), 134-153, at 137.

${ }^{7}$ Nicole Alecu de Flers, "Theorizing the Effects of CFSP on National Foreign Policy and the Concept of Europeanization" (paper presented at FORNET Plenary Meetings, "Theoretical Perspectives on the CFSP: New Scholars' Roundtable"), accessed at http://www.fornet.info/fornetplenarymeetings. html, 11 January 2009.

${ }^{8}$ Robert Ladrech, "Europeanization of Domestic Politics and Institutions: The Case of France," Journal of Common Market Studies 32 (March 1994): 69-87, at 69.

${ }^{9}$ Joseph S. Nye, Soft Power: The Means to Success in World Politics (New York: Public Affairs, 2004).

${ }^{10}$ Helene Sjursen and Karen E. Smith, "Justifying EU Foreign Policy: The Logics Underpinning EU Enlargement," ARENA Working Papers WP 01/1, 2001, accessed at http://www.arena.uio.no/ publications/working-papers2001/papers/wp01_1.htm.
} 
economic, and other peaceful ways of settling conflicts are considered more legitimate than others while attempting to reach lasting solutions to border disputes.

\section{Process}

This means that the decision-making process in foreign and security policy realms becomes increasingly "civilianized." Elected civilians and nongovernmental civil society organizations become more influential in defining foreign policy interests than appointed bureaucrats. ${ }^{12}$ People who are in charge of policymaking make their decisions in transparent settings and are held accountable to the public for the consequences of their behavior.

This also suggests that the classic difference between high politics and low politics evaporates as issues become increasingly interlinked during the globalization process. The practice of defining potential security problems as political problems increases, and the idea that the adoption of extraordinary and emergency measures in dealing with security problems is legitimate becomes discredited. The goal becomes the politicization/de-securitization of all potential security problems so that their resolution through bargaining, consensus building, and negotiation becomes possible..$^{13}$ Potential security problems cannot be satisfactorily resolved unless they are redefined as political issues. ${ }^{14}$

\section{Outcome}

This suggests two things. One the one hand, specific foreign policy choices/ positions of countries gradually converge with those of the European Union; on the other hand, some countries aspire to join the EU as members in order to achieve their interests more efficiently. Here, one is talking about the extent to which some countries adopt policies identical to those of the European Union in specific issue areas.

These three dimensions of European-appearing foreign policy do not have to exist simultaneously. A particular country might adopt foreign policy positions on some issues resembling those of the European Union, yet might have

${ }^{11}$ Özkan Duman and Dimitris Tsarouhas, "Civilianization in Greece versus Demilitarization in Turkey: A Comparative Study of Civil-Military Relations and the Impact of the European Union," Armed Forces \& Society 32 (April 2006): 405-423, accessed at http://afs.sagepub.com/cgi/reprint/32/3/ 405, 28 November 2008.

${ }^{12}$ P.C. Ioakimidis, "The Europeanization of Greece: An Overall Assessment," Hellenic Center for European Studies Policy paper (EKEM), 2002, accessed at http://www.ekem.gr/archives/2002/01/ the_europeaniza.html, 26 November 2008.

${ }^{13}$ Karen E. Smith, "Still 'Civilian Power' EU?" (paper presented at the CIDEL Workshop, "From Civilian to Military Power: The European Union at a Crossroads?" Oslo, 22-23 October 2004).

${ }^{14}$ Ole Waever, "Securitization and Desecuritization," in D. Ronnie, ed., On Security (New York: Columbia University Press, 2005), 50. 
an authoritarian and highly militarized foreign policy decision-making process as well as a unilateral and nationalistic foreign policy style.

\section{Europeanization as Cause: True Europeanization}

This concept refers to the fact that Europeanizing foreign policy is shaped by EU-related factors, which mainly concern the dynamics of the EU integration/ enlargement process and the ideational commitment on the part of candidate countries to EU membership. In this sense, one can argue that Turkey's Europeanizing foreign policy could be redefined as the Europeanization of Turkish foreign policy if, and only if, the former were caused by the factors pertaining to the dynamics of Turkey's EU membership process.

True Europeanization appears to be explained by the insights of sociological institutionalism. People in charge of the foreign policymaking process would consider the norms of the European Union's foreign policy as appropriate and legitimate. Adopting them would be seen as fitting in their efforts to help prove their European identity. Sociological institutionalism frequently posits a world of individuals or organizations seeking to define and express their identity in socially appropriate ways. ${ }^{15}$ Europeanization as cause would appear mainly a top-down process in the sense that the hierarchical relationship between the EU and candidate countries would not allow the latter to challenge the normative underpinnings of EU foreign policy. ${ }^{16} \mathrm{EU}$ norms gradually become part of national identities and foreign policy practices throughout the accession process. ${ }^{17}$ Sociological institutionalism would define Europeanization as cause as a process, which may result in redefinition of states' foreign policy identities and preferences in line with the constitutive norms of the European Union.

Long years of coexistence within EU institutional platforms would gradually help bring into existence a common foreign policy understanding intersubjectively shared by member states. Similarly, after a long accession process, candidate countries would begin to redefine their national identities as European and adopt Europeanized foreign policy. Faced with external stimuli, they would not consider whether they needed to adopt European foreign policy.

\footnotetext{
${ }^{15}$ Peter A. Hall and Rosemary C.R. Taylor, "Political Science and the Three New Institutionalisms," Political Studies 44 (December 1996): 936-957, at 949, accessed at http://www.mpifg.de/pu/mpifg_dp/ dp96-6.pdf, 24 November 2008.

${ }^{16}$ Wong, "Europeanization of Foreign Policy," 142.

${ }^{17}$ Speech given by Anna Fotyga, the Polish Foreign Minister, at the Conference of the European Union Institute for Security Studies and European Center Natolin: Europe as a Global Power WarsawNatolin, 19 May 2006, accessed at www.natolin.edu.pl/pdf/FN/FN_2_2006_fotyga.pdf, 12 December 2008; Gordan Jandroković, Croatia's Foreign Minister, "Croatia says it will do 'whatever it takes' to join EU in 2010," statement given at a press conference with Enlargement Commissioner Olli Rehn, 7 April 2008, accessed at http://www.euractiv.com/en/enlargement/croatia-takes-join-eu-2010/article171488, 18 December 2008.
} 
Whether the EU is a civilian, normative, soft, hard, or realpolitik actor, what matters is that candidate states would act out of the conviction that adopting EU foreign policy norms would accord with their Europeanizing identity. ${ }^{18}$

For sociological institutionalism to make sense in the context of Turkish foreign policy, one needs to prove that the normative underpinnings of EU foreign policy need to be seen as legitimate at home. Faced with external challenges, the first question Turkey would ask should be how an EU candidate country should behave in this situation. Put another way, Turkey should act on the logic of appropriateness. Rather than questioning EU intentions on its membership status and indexing the degree of its own Europeanization to the EU's rewarding attitudes, the logic on the part of Ankara should be that the more a country proved its European identity, in this context through foreign policy, the more difficult would be justifying its exclusion from the EU on the basis of identity. ${ }^{19}$

${ }^{18}$ The literature on the EU is replete with alternative accounts of the EU as a foreign policy actor. Some claim that the EU is a typical soft power that takes its legitimacy from the attractiveness of its own model in the eyes of third parties. Soft-power EU simply leads by example; others argue that the EU is more a civilian actor than a military one, which employs non-military instruments in order to achieve its interests abroad; others posit that the EU is in fact a sui generis normative actor that tries to shape its milieu in its own image by dint of normative means, whatever they are. The EU is powerful simply because its internal practices define the standards of appropriate/normal behavior in the international arena. The EU is built on norms such as the rule of law, liberal democracy, respect for human rights, and free-market economy, and it tries to project them onto others with a view to transforming them. Others point out that the EU is a typical imperial power that pursues sometimes normative, sometimes realpolitik interests and strategies, with a view to helping create a ring of friendly countries under its own influence. See Jean-Jves Haine, "The EU's Soft Power: Not Hard Enough?" Georgetown Journal of International Affairs 5 (Winter/Spring 2004): 69-77, accessed at http://journal. georgetown.edu/issues/ws04/hainelocked.pdf, 4 December 2008; Joakim Kreutz, "Hard Measures by a Soft Power? Sanctions Policy of the European Union 1981-2004," Bonn International Center for Conversion, 2005, Paper 45, 1-50, accessed at http://www.bicc.de/uploads/pdf/publications/papers/ paper45/paper45.pdf, 5 December 2008; Francois Duchene, "Europe's Role in World Peace," in R. Mayne, ed., Europe Tomorrow: Sixteen Europeans Look Ahead (London: Fontana, 1972), 32-47; Stelios Stavridis, "Why the 'Militarizing' of the European Union is Strengthening the Concept of a Civilian Power Europe" (EUI working paper RSC 17, 2001), 1-21, accessed at http://cadmus.eui.eu/ bitstream/handle/1814/1726/01)17.pdf?sequence=1; Ian Manners, "Normative Power Europe Considered: Beyond the Crossroads," Journal of European Public Policy 13 (March 2006): 182-199; Ian Manners, "Normative Power Europe: A Contradiction in Terms?" Journal of Common Market Studies 40 (June 2002): 235-258; Helene Sjursen, “The EU as a 'Normative' Power: How Can This Be?” Journal of European Public Policy 13 (March 2006): 235-251; Bjorn Hettne and Fredrik Soderbaum, "Civilian Power or Soft Imperialism? EU as a Global Actor and the Role of Interregionalism," European Foreign Affairs Review 10 (2005): 535-552.

${ }^{19}$ This kind of Europeanization is totally different from the bottom-up Europeanization that can be defined as the externalization of national foreign policy interest onto the EU level from a tactical/ instrumental perspective; see Wong, "Europeanization of Foreign Policy," 137. Here, the institutional platforms of the European Union would be deemed strategically vital in the materialization of key national foreign policy interests. The success of bottom-up Europeanization can be measured against the extent to which the EU's foreign policy principles and priorities would change in line with the 


\section{Describing Apparent Europeanization of Turkish Foreign Policy}

This section offers an empirical account of Turkey's apparent Europeanization in terms of style, process, and outcome dimensions. The goal is simply to demonstrate the changes on the ground. The underlying causes of these changes will be dealt with in the following sections.

\section{In Terms of Style}

Recently, Turkey's efforts to pursue its foreign policies in regional and multilateral platforms have accelerated. The goal of diplomacy has been redefined as achieving win-win outcomes for all parties involved, rather than imposing Turkey's will on the others. ${ }^{20}$ The old distinction that was assumed to exist between the domestic and external realms is no longer considered by Turkish foreign policymakers to be valid. It is now the case that Turkey's relations with third parties are seen as complementary to each other. Besides, Ankara has begun to see foreign policy as a distinctive policy realm, in which pursuing competitive relations with other actors no longer justifies unchangeable selfother categorization. ${ }^{21}$ The "zero problems with neighbors" approach of the current AKP government appears to reflect this understanding.

This approach seems to aim at paving the way for regional integration in Turkey's neighborhood whereby growing interdependent relations would decrease the possibility of resorting to and use of brute force in dealing with potential security problems. Ankara now acts on the assumption that growing regional economic, social, and political interdependence on the one hand and internal liberal-democratic transformation on the other are needed for the emergence of EU-like security communities in its neighborhood.

In this context, Turkey's support for liberal democratic reforms in the Islamic world is worth mentioning. For example, in 2004, then-Turkish Foreign Minister Abdullah Gül recommended in the summit meeting of the Organization

priorities of the initiator country. That said, this kind of Europeanization will apply only to member states, for other countries, particularly candidate countries, would be devoid of the capabilities of having access to the EU's institutional platforms. The best example in this context can be found in Greece's attempts at realizing its security interests vis-à-vis Turkey through the prerogatives of its EU membership. ${ }^{19}$ Greece has long tried to Europeanize its foreign policy interests vis-à-vis Turkey in an effort to extract as many concessions as possible from Turkey while the latter was trying to join the EU. The hope in Athens was that if Greece succeeded in masquerading its national policies vis-à-vis Turkey as European, its leverage vis-à-vis Turkey would increase. Greece would be successful if bilateral Turkish-Greek problems were redefined as Turkey-EU problems. See Panayotis Tsakonas, "Theory and Practice in Greek Foreign Policy," Southeast European and Black Sea Studies 5 (September 2005): 427-443.

${ }^{20}$ Kemal Kirişci, "Between Europe and the Middle East: The Transformation of Turkish Foreign Policy," Middle East Review of International Affairs 8 (March 2004): 39-51, at 48.

${ }^{21}$ Sylvia Tiryaki, "Multidimensional Turkish Foreign Policy," Turkish Daily News, 2 June 2008, accessed at http://www.turkishdailynews.com.tr/article.php?enewsid=106074, 3 December 2008. 
of the Islamic Conference (OIC) that the Muslim world implement radical reforms in the realms of democracy and human rights. ${ }^{22}$ Similarly, Prime Minister Erdoğan expressed the need for change and reformation in the Islamic world on various issues ranging from freedom of speech to women's rights. On one of those occasions, he prioritized democracy as the path through which the countries in the Islamic world should be governed. ${ }^{23}$

One recent example in this regard pertains to Turkey's leading role in the Organization of the Islamic Conference. With its 57 member states spread over four continents, the OIC is the second largest inter-governmental organization after the United Nations. Since 2005, Ekmeleddin İhsanoğlu of Turkey has been in charge of the OIC as Secretary General. Turkey has also gained observer status in the Arab League. Turkey's growing international profile attests to its inclination to pursue its interests through multilateral platforms.

This approach is not solely confined to the Middle East. Turkey's efforts in finding solutions to emerging security challenges through regional and universal institutional settings becomes evident when one takes note of Turkey's pioneering role in the Black Sea Economic Cooperation Organization, the Southeast European Cooperative Initiative, etc. ${ }^{24}$ Specifically in the Balkans, Turkey contributes to various regional initiatives with objectives ranging from traditional peacekeeping to stabilization, to supporting Balkan countries' integration into the European Union and the North Atlantic Treaty Organization (NATO).

Turkey now tries to solve its security problems abroad by adopting diplomatic and economic instruments. Turkey has radically changed its approach toward Athens over the last decade. Greece is no longer seen as among the main threats to Turkey's security interests, and Ankara increasingly values the growing economic relations with Greece as key to peace in the region. Turkey supported the so-called Annan Plan in the process of the settlement of the Cyprus dispute and has recently made a new opening to the Republic of Armenia. ${ }^{25}$ The same

\footnotetext{
${ }^{22}$ Yakup Beris and Aslı Gürkan, "Broader Middle East Initiative: Perceptions from Turkey," Turkey in Focus 2 (TUSIAD Publication, July 2004), accessed at http:/www.tusiad.us/Content/ uploaded/TURKEY-AND-BROADER-MIDDLE-EAST-TURKEY-IN-FOCUS-ISSUE7-FINAL. PDF, 7 December 2008.

${ }^{23}$ Recep Tayip Erdoğan, "Din üzerinden siyaset suikasttir" ("Politics Through Religion is Suicide"), Hürriyet, 7 July 2005, accessed at http://webarsiv.hurriyet.com.tr/2005/07/07/668772.asp, 5 January 2009.

${ }^{24}$ Southeast European Cooperative Initiative (SECI), which comprises 12 member countries in Southeast Europe and aims at curbing trans-border crime, is just one example of those regional initiatives; Turkey contributes not only to policing operations led by NATO or EU like SFOR, KFOR, 'Operation Concordia,' or EU's policing mission in Bosnia, but also takes part in several regional initiatives aimed at improving the Balkan region in different areas. For more information see Güner Öztek, "Situation in the Balkans and Turkey's Balkan Policy," 2004, accessed at www. obiv.org.tr/2004/Balkanlar/001-GUNER\%20OZTEK.pdf, 13 January 2009.

${ }^{25}$ Bülent Aras and Fatih Özbay, "Turkish-Armenian Relations: Will Football Diplomacy Work?" SETA Policy Brief 24 (September 2008), accessed at http://www.setav.org/index.php?option=com content \&task = view\&id=571\&Itemid=68, 13 March 2009.
} 
approach is also observable in Turkey's recent adoption of the liberal-integrationist approach toward the Kurds of northern Iraq.

Another policy that appears European is that Ankara pursued a vigorous diplomatic campaign across international platforms before making the decision to strike at the PKK (Kurdistan Workers Party) strongholds in northern Iraq in late 2007. In the past, Turkey organized dozens of cross-border operations but rarely cared to secure international legitimacy. ${ }^{26}$

The other development worth of mentioning in this regard is Turkey's increasing efforts to play mediating roles in political/security problems in the Middle Eastern region. The recent examples include Ankara's efforts to help broker an agreement between Israeli and Syrian diplomats through indirect negotiations held in Istanbul, to help mediate between the Israeli government and the Palestinian Authority, particularly following the latest clashes between the Israeli army and Hamas in Gaza, to assist the dialogue between the European Union and Tehran, to bring the Afghan and Pakistani presidents to Ankara, and finally, to offer the Caucasia Stability and Cooperation Platform in the wake of the latest clashes between the Russian and Georgian armies over the status of two Georgian enclaves, Abkhazia and Southern Ossetia. ${ }^{27}$ All such Turkish initiatives have been positively received by highlevel EU officials. The latest progress report on Turkey, which is issued by the European Commission on candidate countries, praises Turkey's effort to contribute to regional peace and stability through these initiatives.

\section{In Terms of Process}

Recent years have also witnessed the growing role of civilians in the foreign policymaking process. For example, institutional reforms in the National Security Council (NSC) caused a reshuffling of power in the process of foreign policymaking. The seventh reform package, which was passed on 23 July 2003, curtailed the military representation in the NSC. The decisions of the NSC are now advisory. The council now meets every two months, and its secretary general is a high-level civilian bureaucrat. Non-governmental civil society organizations, business associations, and economic interest groups have become influential actors in Turkish foreign policy as Turkey's integration into global economic structures has deepened. Think tanks have also come to the fore as key sites of foreign policy debates.

Another development in this context is that foreign and security policy issues are now being discussed among the public to an extent one would have

\footnotetext{
${ }^{26}$ Gündüz S. Aktan and Ali M. Köknar, "Turkey," in Y. Alexander, ed., Combating Terrorism: Strategies of Ten Countries (New Delhi: Manas, 2003), 278-281.

${ }^{27}$ Bülent Aras, "Turkey between Syria and Israel: Turkey's Rising Soft Power," SETA Policy Brief 15 (2008), accessed at http://www.setav.org/index.php?option=com_content\&task =view\&id $=472 \&$ Itemid=68, 15 April 2009.
} 
found unbelievable 10 years ago, particularly concerning relations with the EU, Cyprus, northern Iraq, Russia, and Armenia. ${ }^{28}$ The process of framing potential security issues as political issues is also becoming more evident (northern Iraq, Cyprus, and Armenia are the leading examples). ${ }^{29}$ It is of importance that the recent changes in the Turkish approach toward the Cyprus dispute and Armenia have become possible through the active agency of business groups and civil society organizations. Increasing civilianization has contributed to the politicization of erstwhile hard-core security issues. The latest initiative on the need to apologize for the suffering of the Armenians during the so-called Armenian genocide in the course of World War I is a prime example of the growing influence of civilians on taboo issues. This apology campaign was organized by prominent intellectuals and supported by a quite number of Turkish people. Another example in this context is that lately the high military brass have decreased their public profile when foreign and security policy issues are discussed. They are now more reticent to make public comments on sensitive issues.

\section{In Terms of Outcome}

In terms of the degree of convergence between the foreign policy choices of Turkey and those of the European Union, one can argue that there has been a high degree of convergence in the Balkans and Caucasus (except Armenia) ${ }^{30}$ a growing degree of convergence in the Middle East (similar views on Iran, Iraq, Syria, and the Israeli-Palestinian dispute), a limited degree of convergence in the greater Black Sea region, including Russia, a high degree of convergence

\footnotetext{
${ }^{28}$ Alan Makovsky and Sabri Sayarı, "Introduction," in Alan Makovsky and Sabri Sayarı, eds., Turkey's New World: Changing Dynamics in Turkish Foreign Policy (Washington, DC: Washington Institute for Near East Policy, 2000), 1-8. The situation is put forward as such: "Much of Turkish foreign-policy decision-making is shrouded in secrecy. Still, it can be safely said that the emergence of a stronger presidency and National Security Council over the last two decades of the twentieth century has increased the number of poles in Turkey's "multi-polar" decision-making apparatus. The primary reference points now seem to be the presidency, prime ministry, and military, with the foreign ministry nevertheless still an important player. Which takes the lead in a crisis seems to be a matter of personality, political circumstance, and the issue at hand." Little role used to be attributed to the public and think tanks. However, with the EU process, foreign and security policy became issues of public and open debate. Once, the multi-polarity in foreign policy decision making meant involvement of the presidency, prime minister, ministry of foreign affairs, and military in the process. However, now the process inevitably includes the public, media, think tanks, business associations, and so forth.

${ }^{29}$ Ayşe B. Çelik and Bahar Rumelili, "Necessary But Not Sufficient: The Role of the EU in Resolving Turkey's Kurdish Question and the Greek-Turkish Conflicts," European Foreign Affairs Review 11 (2006): 203-222.

${ }^{30}$ Katinka Barysch and Charles Grant, "Dealing with Risk: If Turkey and Europe Break Up," Center for European Reform Bulletin Article (2006), accessed at http://www.cer.org.uk/pdf/barysch grant_wef_turkey_nov06.pdf, 11 March 2009.
} 
in Central Asia, and a limited degree of convergence in relations with the United States. ${ }^{31}$

In the Balkans, Turkey supports EU policies of regional integration. To Ankara, the incorporation of the countries of the region into the Western international community through NATO and EU enlargement is the recipe for peace and stability.

Turkey's policies in the Middle East also appear European. Turkey now clearly supports liberal-democratic reforms in the region, yet thinks that such processes should not be imposed on the current regimes from the outside. Likewise, regarding the European Union, Ankara holds that internal dynamics need to be strengthened. Turkey's support for democracy can be seen in Ankara's participation in the Broader Middle East and North Africa Initiative as the democracy partner and the UN-led Alliance of Civilizations Initiative as one of the co-chairs. Ankara pays significant attention to improving its economic relations with neighbors and supports EU-led initiatives to constructively engage Syria and Iran. To Ankara and Brussels, the way to peace in the region passes through the incorporation of the regimes in Damascus and Tehran into the international community and the elimination of the structural causes of the Israeli-Palestinian dispute. Likewise, with regard to the European Union, Turkey has strongly criticized the use of overwhelming force by the Israeli army against the Palestinians in Gaza and voiced the view that Hamas needs to be incorporated into the peace talks as a legitimate party.

Turkey's apparent EU-oriented foreign policy took an upward turn when Ankara dispatched its troops to Lebanon to take part in the EU-led peacekeeping operation that was deployed to the region in the summer of 2006.

Similar to the EU, Ankara values the continuation of Iraq's territorial integrity and the resolution of Iraq's ethnic and religious problems within the framework of internal liberal-democratic reforms. Turkey and the EU also see eye to eye concerning the transportation of Iranian and Turkmen gas to European markets through Anatolia. Both support the so-called Nabuco pipeline project in terms of the efforts to decrease dependency on Russian oil and gas. They have similar views on energy security. Turkey's convergence with EU priorities also became noticeable when Ankara tried to justify its non-cooperation with the United States on the eve of the Iraq war by referring to the strong French-German opposition to U.S. policies. Similar to the EU, Turkey supports a global system that operates on the basis of international law, international organizations, and international legitimacy. Both oppose the transformation of NATO into a global collective security organization that would serve as a tool kit for the United States.

Turkey's convergence with the European Union concerning Russia is somewhat limited. Despite the fact that Ankara shares the EU's view that

\footnotetext{
${ }^{31}$ Kemal Kirişçi, Turkey's Foreign Policy in Turbulent Times (Paris: Institute for Security Studies, Chaillot Paper 92, 2006), accessed at http://aei.pitt.edu/7409/01/chai92.pdf, 15 February 2009.
} 
Russia should transform into a liberal-democratic country and become a responsible member of the international community, Ankara also supports the Russian claim that EU and NATO eastward enlargement should not be realized at the expense of Moscow's security concerns. From Ankara's point of view, the West should treat Russia with respect and the current tension in Russia-West relations should not put Turkey's improving relations with Russia into jeopardy. ${ }^{32}$

\section{Explaining Apparent Europeanization of Turkish Foreign Policy}

\section{Europeanization as Cause: How Relevant Is It?}

The goal here is to determine whether the recent changes in Turkish foreign policy, as described in the previous section, have been caused by the dynamics of Turkey's EU accession process and Turkey's perception of EU foreign policy norms as legitimate. What are the limits of Europeanization as cause?

It would not be an over-estimation to argue that the radical reforms undertaken in relation to the National Security Council have been done at the urge of the European Union. The emerging consensus that security cannot be achieved at the expense of democratization and human rights might also owe its existence to the ongoing EU accession process. Improving relations with Greece, Cyprus, Syria, and Armenia, as well as the adoption of soft-power instruments abroad, might also have been impacted by the EU's demand that Turkey's prospective membership would only be possible if Ankara developed good relations with its neighbors. ${ }^{33}$ After all, one specific chapter of the entire negotiation package concerns harmonization of Turkish foreign policy with EU foreign and security policy. That said, the style and process dimensions of Turkey's Europeanizing foreign policy might have been informed by the dynamics of the EU accession process.

However, this analysis should not lead to a conclusion that all such changes suggest the strengthening of ideational commitment on the part of Turkish elites toward EU membership, for recent years have witnessed growing degrees of Euro-skepticism in Turkey. This has been the case despite the start of the formal negotiations in October 2005, and can best be observed in the declining support that Turkey's traditionally Western-oriented elites are giving the EU project. These circles have increasingly begun to question the rationale of Turkey's

${ }^{32}$ Hasan Ali Karasar, "Saakashvili Pulled the Trigger: Turkey between Russia and Georgia," SETA policy brief (August 2008), accessed at http://www.setav.org/index.php?option=com_content\&task= view\&id=545\&Itemid=68, 11 May 2009.

${ }^{33}$ EU Helsinki Summit Resolutions, accessed at http://www.europarl.europa.eu/summits/hel1_en. htm, 9 November 2008; Negotiation Framework Document, accessed at http://www.abgs.gov.tr/ files/AB_Iliskileri/Tur_En_Realitons/NegotiatingFrameowrk/Negotiating_Frameowrk_Full.pdf, 14 November 2008. 
EU vocation on the grounds of structural incompatibilities between the foundational logics of the Turkish Republic on the one hand and the EU integration process on the other. These circles fret that the Europeanization process might in the end result in the weakening of Turkey's unitary, homogenous, and secular state identity; that Turkey might one day come out of this process as a federated/ decentralized state with Turkish society transforming into a multi-cultural entity alongside ethnic, religious, and linguistic differences. That is why these circles have viewed the AKP-led Europeanization reforms in recent years through skeptical eyes. The possibility that Islam's public role might increase alongside the ongoing liberal-democratic reforms has added additional insult to the injury. Given this, these circles have not hesitated to resort to some non-democratic means in the recent past, with a view to preventing the allegedly Islamist AKP from electing its candidate to the presidency in early 2007.

Interesting to note in this context is that the so-called ulusalcilik movement has recently come to the fore as an alternative foreign policy ideology, reflecting many of the reservations of Turkey's traditional security elites ${ }^{34}$ To the adherents of this view, it would be better if Turkey were to pursue an Eurasianist foreign policy, rather than aspiring to come closer to the West. To them, the West does not treat Turkey as a legitimate member of the Western international community. Rather than this being the case, they see Turkey as a buffer zone separating the EU's Kantian security environment from the Hobbesian security environment in the greater Middle East. The Western approach toward Turkey is instrumental in the sense that the West indirectly supports Turkey's transformation into a moderate Islamic country so that the West could better deal with radical Islam. This Western conceptualization of Turkey prioritizes Turkey's Islamic and Middle Eastern identities. This fits in perfectly with the AKP's conceptualization of Turkish foreign policy interests, particularly in the context of the Middle East. That said, these circles believe that Turkey's transformation alongside the EU accession process will paradoxically strengthen Turkey's Islamization and Middle Easternization, contradicting the gist of Turkey's traditional Westernization process.

Such influential members of traditional security elites as retired general Tuncer Kilic have even argued that Turkey's links to the Western international community should be severed and that Turkey should follow a Eurasianist foreign policy course. This suggests that relations with Russia, China, and Iran should be improved, so much so that Turkey would form strategic partnerships with these countries. To these elites, Turkey's membership in NATO and the dynamics of the EU accession process limit Turkey's maneuvering capability abroad. The demands of the EU membership process are reminiscent of the still-born Treaty of Sèvres that the victorious powers of World War I tried to impose on the Ottoman Empire in 1920.

\footnotetext{
${ }^{34}$ Emrullah Uslu, "Ulusalcilik: The Neo-nationalist Resurgence in Turkey," Turkish Studies 9 (March 2008): 73-97.
} 
What seems to be a paradox is this regard is the fact that these circles have traditionally supported Turkey's European vocation and equated it to Turkey's modernization/civilization process, yet they have recently turned into the most ardent opponents of the EU process. One factor that might explain this is that these circles would certainly lose some of their prerogatives in the making of Turkey's foreign and security policy decisions alongside the changes in the style and process dimensions of Turkish foreign policy.

Another factor that appears to have diluted Turkey's identity-based commitment toward EU membership can be attributed to the instrumental/consequential logic on the part of the AKP government toward the EU. It has gradually become clear that this Party does not attach a strong ideational commitment to Turkey's prospective EU membership in the sense that such an outcome would eventually help confirm Turkey's European identity irreversibly.

Analysts still discuss to what extent the ruling AKP sincerely supports Turkey's European vocation. Suspicions particularly linger on the intentions of the Party to view the Europeanization process from an instrumental perspective in an effort to help further Islamize Turkish society. For example, the key figures of the Party have not minced words in criticizing European institutions, most notably the European Court of Human Rights, when the latter made it clear that the wearing of headscarves (turbans, in Turkey) could be prohibited in public places if it was perceived as a threat to Turkey's secular identity. The AKP has slowed the pace of the EU reform process over the last three years, lest the Party lose ground to the circles that might possibly thrive on the growing feeling of Euro-skeptic nationalism. Against such developments, it would not be wrong to state that a nationwide consensus is still missing on the appropriateness of Turkey's efforts to join the EU from an identityrelated perspective.

Another factor that has equally contributed to the erosion of Turkey's ideational commitment to the EU is the growing European opposition to Turkey's possible inclusion in the EU on the basis of inherent identity differences. ${ }^{35}$ Paradoxically, opposition to Turkey's possible EU membership has increased despite the fact that Turkey has institutionally come closer to the EU than ever following the initiation of the formal accession negotiations in October 2005. Despite the fact that the coming to power of the AKP initially helped boost Turkey's soft power in the eyes of European circles on the grounds that Turkey could be the prime example of Islam and liberal democracy coexisting peacefully, sympathy toward Turkey has gradually waned as many Europeans have begun to define Islam as one of the potential others of the secular multicultural EU. Turkey's ideational commitment to the EU

\footnotetext{
${ }^{35}$ Lauren M. McLaren, "Explaining Opposition to Turkish Membership in the EU," European Union Politics 8 (June 2007): 251-278; Claes H. de Vresse, Hajo G. Boomgaarden, and Holli A. Semetko, "Hard and Soft Public Support for Turkish Membership in the EU," European Union Politics 9 (December 2008): 511-530.
} 
weakened further when the European Union did not kept its promise of easing the trade embargo on the Turkish Republic of Northern Cyprus following the approval of the so-called Annan Plan by Turkish Cypriots; when such figures as Angela Merkel and Nicolas Sarkozy argued that Turkey should be offered the privilege of partial membership rather than full membership; when the French and Austrian governments made it clear that they would bring the issue of Turkey's membership to the public referenda; when the Negotiation Framework Document stated that the negotiation process with Turkey would be open-handed and the EU would take into consideration its absorption capacity in deciding on whether to admit Turkey; and when some EU members, such as France, asked Turkey to recognize what happened during the course of the World War I in relation to the Armenian subjects of the Ottoman Empire as genocide.

Based on this analysis, one expects to see that Turkey's foreign policy would not evolve in line with EU norms and practices and that opposition to Turkey's EU membership would decrease. However, rather than this being the case, Turkish foreign policy has in recent years gained a European outlook. For example, the ex-Chief of Staff, Hüseyin Kıvrıkoğlu, openly stated that membership in the EU has become a geopolitical necessity on the part of Turkey. ${ }^{36}$ The sections that follow try to demonstrate this.

\section{Realpolitik Concerns to Soft-balance the United States}

It is the U.S. policies in Iraq and the Middle East that have recently impacted Turkey's foreign and security policy interests the most profoundly. The U.S.led war in Iraq and the American policies toward democracy promotion during the post-September 11 era have caused consternation in Ankara primarily because such policies appear to have shaken up the status quo with which Turkey has not been at odds. Ankara felt quite discontented with the growing instability in Iraq following the ouster of Saddam Hussein's regime. As the possibility of Iraq's disintegration along ethnic and religious lines and of the formation of an independent Kurdish state in northern Iraq increased, the United States appeared as a potential security threat to Ankara rather than a security provider. ${ }^{37}$

The same logic also holds true as far as Turkey's disillusionment with U.S. policies toward Syria and Iran are concerned. Whereas Washington tended to define these countries as parts of the infamous "axis of evil" and as needing to

\footnotetext{
${ }^{36}$ Fikret Bila, “Kıvrıkoğlu: Yüzümüz Batıya Dönüktür” (“Our Face Is Towards Europe”), Milliyet, 23 January 2009, accessed at http://www.milliyet.com.tr/Yazar.aspx?aType=YazarDetayArsiv\& ArticleID =1050987\&AuthorID =61\&b=Kivrikoglu:\%20Yuzumuz\%20Batiya \%20donuktur\&a = Fikret\%20Bila, 16 February 2009.

${ }^{37}$ Ayşegül Sever, "Turkey and U.S. on Iraq since the Gulf War," Turkish Review of Middle Eastern Studies 13 (Annual 2002/2003): 24-39, at 33.
} 
be contained through every possible means available, Ankara not only thought that peace and stability in the region could in no way be achieved without the inclusion of Damascus and Tehran in the larger Middle East peace process, but also has expended great effort to improve its own relations with them over the last decade. ${ }^{38}$ Given that Turkey and Syria were on a collision course over the PKK (an ethnic Kurdish terrorist organization operating in southeast Turkey) nearly a decade ago, observers are now surprised by the growing economic, political, and security ties between the two countries. There is now a free-trade agreement in existence, and Syrian leaders value Turkey's role as facilitator in the Middle East peace process. The point that needs to be underlined here is that the start of the accession talks with the European Union has positively contributed to Turkey's regional standing, as well as making it possible for Turkey's calls for liberal democratic transformation to be received positively.

Turkey's coming closer to the European Union in the post-Iraq war era is the result, in part, of the changing dynamics of Turkish-American relations over the last years. This process in fact started following the dissolution of the Soviet Union but reached its climax in the aftermath of the U.S.-led occupation of Iraq. Simply stated, Turkey hopes that it could better balance the United States through its institutional links to the European Union. Joining the EU as a member, Europeanization as outcome, would help crown Turkey's ability to counterbalance the United States. This has been necessitated by the declining significance of NATO as a Europe-oriented collective defense organization in which Ankara could interact with Washington multilaterally. Membership in NATO no longer suggests that Turkey and the United States share similar threat perceptions. Turkey's membership in NATO no longer implies that Turkey is a European country and that strong American backing improves the prospects of its membership in the EU. To Ankara, NATO is no longer a Europe-oriented collective defense alliance in which the credentials of Turkey's European identity are fully recognized. The more NATO turned out to be a collective security organization with a global reach, the less likely was Turkey to legitimize its own European identity on the basis of its NATO membership. The fear on the part of Ankara has long been that the more bilateral the relations turned out to be, the more leverage the United States

38 “Turkish Foreign Minister Abdullah Gül on Saturday December 26, 2005 dismissed reports that the US had offered a deal to attack the PKK Kurdish organization in return for allowing an attack on Iran.... Turkey has long strategic relations with USA, however, the relations between Turkey and neighboring Iran have also improved in remarkable ways in recent years following reciprocal trust boosting measures," reported by Arabic News, accessed at http://www.arabicnews.com/ansub/Daily/ Day/051226/2005122618.html, 17 February 2009. In addition, on various occasions, former Foreign Minister Gül and Prime Minister Erdoğan repeated that Turkey is in favor of a diplomatic solution with Iran and Syria. See "The Turkish Passage Dar al Hayat," accessed at http://english.daralhayat. com/opinion/OPED/04-2008/Article-20080428-95667781-c0a8-10ed-01e2-5c7325258e03/story.html 17 December 2008; Taha Akyol, “Gül's İran Misyonu” (“Gul's Iran Mission”), Milliyet, 26 June 2006, accessed at http://www.milliyet.com.tr/2006/06/26/yazar/akyol.html, 18 December 2008. 
would have on Turkey. From this perspective, Turkey's bargaining power vis-à-vis the United States would certainly increase following its membership in the EU. ${ }^{39}$

Recent years have made it clear that the United States cannot offer Turkey a long-lasting strategic relationship reminiscent of the Cold War era. Its commitment to Turkey's territorial security is no longer guaranteed. U.S. and Turkish security priorities have begun to diverge over the last decade. The United States and Turkey do not see eye to eye on the way in which security threats and terrorism are defined and on how to cope with them. ${ }^{40}$ PostSeptember 11-era developments have contributed to this drifting apart. The perception that siding with the United States would benefit Turkey's security interests has gradually become discredited as both capitals have adopted diametrically opposing views on as many issues areas as possible, such as Iraq, PKK terrorism, Syria, Hamas, and Iran. For example, despite all its reservations, Turkey finds the European approach to the Kurdish question in the Middle East more acceptable than the American approach. While the EU appears to believe that the misery of the Kurdish people in the region should be ended through internal liberal democratic reforms within the internationally recognized borders, Washington appears to be predisposed toward the idea that an independent Kurdish state is what might be needed in this regard. ${ }^{41}$

Even though the end of the Cold War in the early 1990s made it clear that the dynamics of Turkey's relationship with the United States would no longer reflect the close strategic relationship of the past, Turkish decision makers have long failed to grasp the changing realities on the ground. Gone were the good old days during which the U.S. commitment to Turkey's security within the framework of NATO was undisputed. Rather than grasping this, Ankara has tended to believe that the rise of the Middle East in the strategic priorities of the United States would elevate Turkey's status in Washington to a higher place than was the case during the Cold War era. Ankara also assumed that U.S. support for Turkey's membership in the EU would help accelerate the process of Turkey's inclusion in the EU. ${ }^{42}$

${ }^{39}$ Ian O. Lesser, "Turkey, Greece, and the U.S. in a Changing Strategic Environment," testimony before the House International Relations Committee, Europe Subcommittee CT- $179,107^{\text {th }}$ Cong., $1^{\text {st }}$ sess., (13 June 2001), accessed at http://www.rand.org/pubs/testimonies/2005/CT179.pdf, 12 April 2009; Lesser, a senior analyst at RAND specializing in Mediterranean and strategic affairs, explained in his testimony before The House International Relations Committee that we may not wish to see Turkish attitudes toward Iraq or Iran further "Europeanized."

${ }^{40}$ Rajan Menon and S. Enders Wimbush, "Is the United States Losing Turkey?" Hudson Institute White Papers (2007), 1-41, accessed at http://www.hudson.org/files/pdf_upload/Turkey\%20PDF.pdf, 13 December 2008.

${ }^{41}$ Nihat Ali Özcan and M. Hakan Yavuz, "Kurdish Question and Turkey's Justice and Development Party," Middle East Policy 13 (Spring 2006): 102-119.

${ }^{42}$ Statement given by the Turkish Foreign Minister, Ali Babacan, at a press conference in Washington, The United States Mission to the European Union, accessed at http://useu.usmission.gov/Article.asp? ID=31F390DB-BA6A-4FA0-BE0F-A97E3B6C2D5D, 11 February 2009. 
However, the so-called strategic partnership between the two capitals in the late 1990s only became possible due to conjectural convergence of Turkish and American interests, rather than the shared belief that Turkey and the United States were allies in NATO and that what was good for one would also be good for the other. Instead, the developments on the ground helped prove that the United States valued Turkey's cooperation and supported its EU vocation so long as Turkey helped Washington win the war on global terror, stabilize Iraq, contain Iran and Syria, and secure U.S. access to the oil and gas resources of the Middle Eastern and Eurasia. ${ }^{43}$ Worse, strong American support for Turkey's EU membership has lately begun to backfire by leading to vocal European criticism of U.S. involvement in the EU's own relations with Turkey. Such American support might also have led Turkish decision makers in the past to believe that the EU would have no choice but to let Turkey in the club for strategic reasons. In fact, too much emphasis on Turkey's strategic value has both delayed Turkey's democratization process at home and contradicted the gist of the EU enlargement policy.

On the basis of post-Cold War-era U.S. strategic behavior, as well as of the way in which Washington treated Ankara on the eve of the latest war in Iraq, the AKP leadership appears to have concluded that the United States has transformed into a truly global actor and no longer values long-term alliance relationships with third countries. Save for the United Kingdom and Israel, the United States has no long-term strategic alliances but instead functional cooperative relationships with key countries in particular regions. Turkey is one of those key countries in a strategic region for U.S. interests, the Middle East.

Against such a background, to the AKP leadership and traditional security elites alike, Ankara should never entrust its security to the U.S.-led NATO, but should rather aspire to become part of the European Union. This has gradually become more compelling as the European Union has been developing its own military security capabilities independent of NATO and as Turkey's economic development has increasingly depended on integration with European markets. It is now a widely shared belief in Ankara that Turkey would be better served in dealing with the challenges of globalization as an EU member. As regional groupings have become the key actors in global politics, the need for Turkey to join the EU has increased.

Even though Turkey still attaches a great deal of importance to NATO, it has grown discontent with the idea that NATO could be considered at best a tool kit for the United States. Ankara increasingly questions the credibility of the U.S. commitment to NATO as well as the capability of the Alliance to counter post-Cold War threats, particularly in the context of Afghanistan. ${ }^{44}$

\footnotetext{
${ }^{43}$ Menon and Wimbush, "Is The United States Losing Turkey," 3-5.

${ }^{44}$ Tarık Oğuzlu, "Turkey and the Transformation of NATO," SETA Policy Brief 33 (July 2009), accessed at http://www.setav.org/index.php?option $=$ com_content $\&$ task $=$ view\&id $=892 \&$ Itemid $=57$, 18 February 2009.
} 
This might partially explain why Turkey has been pressing increasingly for inclusion and more-active involvement in European defense planning.

\section{The Impact of the AKP}

Many observers unite around the view that Turkey's march toward Europe accelerated the most during the reign of the AKP government. This article does not deny this, but argues that this has not been caused by the AKP's commitment to the EU from an ideational perspective.

The view that the fight against religiously inspired terror would be better waged in the post-September 11 era if moderate and liberal Islamic circles came to power in predominantly Islamic societies led to a positive reception in the West of the electoral victory of the AKP in 2002. If Turkey succeeded in demonstrating that Islam and democracy could coexist together, this might help the Western international community win the ideational battle against the radical Islamists. This systemic factor can partially explain the growing American support for Turkey's EU membership as well as Turkey's further Europeanization at home and abroad ${ }^{45}$ No doubt the AKP leadership has capitalized well on these emerging global dynamics. On one hand, Turkey participated as a democratic partner in the U.S.-led Broader Middle East and North African Initiative, and on the other, as one of the co-chairs in the UN-led Alliance-of-Civilization Initiative. ${ }^{46}$

A particular motivation that might possibly explain the AKP's willingness to adopt a pro-EU orientation at home and abroad might be that the Party lacked internal legitimacy. Pursuing Europeanizing domestic and foreign policy orientations might have been considered instrumental in helping dispel the fears of Turkey's traditional elites that the AKP has not embraced Turkey's decades-long Westernization process and secular state identity. After all, who would dare think that the AKP's real goal was to transform Turkey into an Islamic society when the pace of Europeanization process accelerated? ${ }^{47}$

Even though the AKP does not define itself as "Muslim democrat" or "political Islamist," many of its critics argue that it represents the continuation of political Islam under a new guise. Therefore, the Party felt the need to define itself either as a post-Islamist party or a conservative democratic party.

\footnotetext{
${ }^{45}$ Sedat Laçiner, "Turkey's EU Membership's Possible Impacts on the Middle East,” Turkish Weekly, 23 March 2007, accessed at http://www.turkishweekly.net/news.php?id=43696, 16 January 2009.

${ }^{46}$ Gökhan Çetinsaya, "The New Middle East, Turkey and the Search for Regional Stability," (working paper, 2008), accessed at http://www.acus.org/programs-relations.asp, 24 February 2009.

${ }^{47}$ Ali Balc1, "Medeniyetler Ittifakı ve AKP" ("Alliance of Civilizations and JDP")," Radikal, 12 November 2006, accessed at http://www.radikal.com.tr/ek_haber.php?ek=r2\&haberno $=6425$, 27 November 2008; Mohammed Ayoob, “Who's Afraid of a Head Scarf?" YaleGlobal, 10 May 2007, accessed at http://yaleglobal.yale.edu/display.article?id=9165, 28 November 2008.
} 
Adopting a Europeanizing foreign policy might have been thought of as bolstering the AKP's institutional identity as such. ${ }^{48}$

The AKP's motivation to accelerate Europeanization as process can also be attributed to the determination of the Party leadership to curtail the political influence of appointed bureaucrats in politics, particularly in the military and judiciary. EU-led democratization would in the end strengthen the civilization process at home..$^{49}$ Foreign policy would become a platform on which the AKP leadership could possibly help erode the undisputed role of the army at home. To the Party, the task of defining Turkey's national interests by elected civilians would be much easier if the role of the army in shaping Turkey's policies on key security and foreign policy issues were challenged. ${ }^{50}$ The Cyprus dispute offers the best example in this context. Turkey's approval of the Annan Plan should not be interpreted as an example of the ETFP (Europeanization of Turkish Foreign Policy). Instead, it constitutes an example of apparent Europeanization that has been mainly informed by AKP's intentions to challenge the primacy and legitimacy of traditional security elites through foreign policy. ${ }^{51}$ Turkey's ideational commitment to EU membership seems to have played a negligible role in this context, if any role at all.

Cooperation with Greece and improvement of relations with other neighbors in the image of EU foreign policy understanding were considered useful strategies through which AKP could shake up the influential position of traditional security elites. After all, the more cooperative and stable relations Ankara developed with neighbors, the less able traditional security elites would be to justify their undisputed roles in the policymaking process. Turkey's changing policy toward Greece also reflects an instrumental/pragmatic concern on the part of the AKP government, in that through rapprochement, Ankara wanted to deny Athens any pretext on which it could veto Turkey's EU accession process.

The AKP's conceptualization of Turkey's foreign policy identity also offers another justification for apparent Europeanization, particularly in terms of Europeanization as style and outcome. The goal of the Party is to help transform Turkey into a "central country," having multiple identities and exerting a leadership role in the surrounding regions. ${ }^{52}$ This would only become possible

\footnotetext{
${ }^{48}$ Mohammed Ayoob, "Political Islam: Image and Reality," World Policy Journal 21 (Fall 2004): $1-14$.

${ }^{49}$ Ayoob, "Who's Afraid of a Head Scarf?"

${ }^{50}$ The party program of the Justice and Development Party, Security, chap 4.5, 14 August 2001, accessed at http://eng.akpatri.org.tr/english/partyprogramme.html\#4.5, 15 December 2008.

${ }^{51}$ Alper Kaliber, "Securing the Ground through Securitized 'Foreign' Policy: The Cyprus Case," Security Dialogue 36 (September 2005): 319-337.

52 "An Eminence Grise: The Visionary behind Turkey's Newly Assertive Foreign Policy," The Economist, 15 November 2007, accessed at http://www.economist.com/world/europe/displaystory. cfm?story_id=10146653, 23 December 2008.
} 
if Turkey adopted a multilateral/regional and soft-power-oriented foreign policy style similar to that of the EU.

To the Party, Turkey is simultaneously a part of various regional security complexes at the same time. Turkey is a European and Middle Eastern country simultaneously. Turkey represents the European world in the Middle East and the Islamic world in Europe..$^{53}$ This approach does not prioritize Turkey's European identity over others. Rather, Turkey under the reign of the AKP has tried to reach the West through the Middle East, and vice versa. The calculation has been that just as the apparent Europeanization would help enhance Turkey's position in the Middle East, Turkey's potential contribution to European security interests in the Middle East would help increase the prospects of Turkey's accession to the EU. One of the best examples that can be offered in this context to help substantiate this claim is Turkey's decision not to participate in the U.S.-led war against Saddam's Iraq in March 2003. This Turkish decision definitely boosted Turkey's standing in the eyes of both Europeans and Muslims in the Middle East. ${ }^{54}$

Rather than adopting an ideational commitment to the EU, the AKP has instrumentally supported the EU membership process so long as this process helped Turkey to transform into a liberal-pluralist polity in the age of globalization, to solve its perennial domestic problems, such as ethnic Kurdish separatism, to reach out to non-European geographies easily, to play a leadership role in its environment, and to be viewed positively by its neighbors. ${ }^{55}$

Regarding the positions the AKP government has adopted on such foreign policy issues as relations with Russia, Iran, Syria, and Iraq, one can argue that Turkey would have possibly adopted the same positions if it had not been negotiating membership with the European Union. The foreign policy doctrine of the new government, as formulated by the chief foreign policy adviser to the Prime Minister, would have dictated soft-power-oriented multilateral interactions with neighbors at any rate. Otherwise, Turkey's leadership potential in its environment in line with the neo-Ottomanist understanding would not have come true.

According to this understanding, Turkey should try to shape its environment by capitalizing mainly on its "strategic depth," which appears to emanate from Turkey's multi-dimensional identity, Ottoman past, and geopolitical location at the crossroads of three continents. ${ }^{56}$ Turkey's capability to make use of its strategic depth in this regard will certainly hinge on its success in making

\footnotetext{
${ }^{53}$ Ahmet Davutoğlu, Stratejik Derinlik Türkiye’nin Uluslararası Konumu (İstanbul: Küre Yayınları, 2004).

${ }^{54}$ Meliha Altunışık, "The Turkish Model and Democratization in the Middle East," Arab Studies Quarterly 27 (January 2005): 1-18.

${ }^{55}$ Recep Tayyip Erdoğan, "Her koşulda barış" ("Peace No Matter What"), Radikal, 1 June 2004, accessed at http://www.radikal.com.tr/haber.php?haberno=117992, 11 April 2009.

${ }^{56}$ Davutoğlu, Stratejik Derinlik, 65-93.
} 
peace with its own multicultural identity and consolidating plural democracy at home.

Neo-Ottomanists argue that the more crosscutting and overlapping networks Turkey could create in its region, the more powerful it would be. ${ }^{57}$ Approaching security from the realpolitik perspective prioritizing self-other distinctions does not fit in with this neo-Ottomanist understanding, for fears of encirclement, dismemberment, and abandonment could only be eliminated through Turkey's engagement in various security complexes simultaneously. This has become more observable in the post-September 11 era. The traditional idea that Turkey's placement in the West would become possible if its links to the Middle East were severed has now been replaced by the understanding that Turkey can now reach to the West through its links to the East and vice versa. ${ }^{58}$

From this perspective, there is nothing wrong with Turkey playing a peacebrokering role in regional disputes and increasing its regional standing. This is an active, agenda-setting, assertive role and in this regard differs from the traditional Kemalist understanding. This ambitious role conception does not, however, suggest that Ankara should try to impose its previously defined national interests on others. Instead, the goal appears to be helping to shape developments in different regions, lest they negatively impact Turkey's interests at home. In this regard, neo-Ottomanism is defensive. Crises around Turkey should be managed or resolved so that Turkey's liberal democratization process can continue unabated at home.

Under the reign of the AKP government, Turkey has of late become a trading state rather than a military state. Otherwise, a defensive, reactive, military-oriented and introvert foreign and security understanding that puts the preservation of Turkey's traditional secular, homogenous, nation-state identity at the top would help legitimize the custodian and guardianship role of the Turkish army.

\section{Realpolitik Concerns to Transform the Middle East and Iraq into a Stable Area}

In the image of the AKP leadership, the Europeanized foreign policy would help improve Turkey's capabilities to deal with the security challenges emanating from the greater Middle Eastern region. A Turkey that acts as a "European" country would be more able to mitigate the negative consequences of the regional insecurity in the Middle East on its national interests at home. This view is now also shared by traditional security elites. ${ }^{59}$

${ }^{57}$ Ibid., 115-119.

${ }^{58}$ Ömer Taşpınar, "Turkey's Middle East Policies between Neo-Ottomanism and Kemalism," Carnegie Papers 10 (September 2008), accessed at http://www.carnegieendowment.org/files/cmec10_ taspinar_final.pdf.

${ }^{59}$ On various occasions, several top-ranking commanders of Turkish armed forces made remarks in this regard; see (Ret.) Chief of General Staff Hilmi Ozkok's New Year's message, 31 December 
As it appears today, the Middle Eastern region looks like a classic textbook example of a Hobbesian security complex, in which the possibility of interstate and intra-state warfare is extremely high. ${ }^{60}$ Worse, the possibility of Turkey being drawn into such a security complex is quite high, given Turkey's proximity to the region as well as its vulnerability to what happens there. ${ }^{61}$

In contrast to the Middle East, the EU represents a Kantian security complex, in which the possibility of using brute force in settling disputes is at an alltime low due to the decades-long integration process in economic, political, and security realms. What Ankara wants is to escape the danger of being a part of the Hobbesian security complex to the south and to become a part of the Kantian security complex to the west. This is simply in Turkey's security interests. For this to happen, two things need to materialize at the same time. On the one hand, Turkey needs to undertake the so-called Copenhagen criteria at home; on the other hand, this internal reformation process need not be negatively impacted by external developments in the Middle East. ${ }^{62}$ This explains why the liberal democratic transformation of the region is now considered a must for the continuation of the same process at home. Turkey's continuing Europeanization at home increasingly requires the transformation of the conflict-producing Middle Eastern region into an EU-like security community in which growing interdependent relations decrease the possibility of the use of force in the settlement of disputes and security is redefined in a postterritorial and post-sovereign manner. Acting as a European country in a typically non-European geography, with a view to playing a transformative role there, is in Turkey's national security interest. It has nothing to do with pleasing the EU.

Turkey's potential to play a facilitator role in this regard would probably increase if Turkey's image in the Middle East improved. For Turkey's messages

2004; accessed at http://www.tsk.mil.tr/10_ARSIV/10_1_Basin_Yayin_Faaliyetleri/10_1_8_Mesajlar/ 2004/yeniyilmesaji_311204.html, 26 December 2008; General Ergin Saygun, (paper presented at symposium on "NATO in Changing Security Environment" ["Değişen Güvenlik ortamında NATO"], 31 May 2007), accessed at http://www.tsk.mil.tr/10_ARSIV/10_1_Basin_Yayin_Faaliyetleri/10_1_7_ Konusmalar/2007/sempozyum_II_bsk_acilis31052007.htm, 24 December 2008. General İlker Başbuğ, opening speech at the symposium on "Evaluation of Regions in Crisis and Their Influence on Turkish Security, from Turkish, NATO and EU Perspectives" (Türkiye, NATO ve AB perspektifinden Kriz Bölgelerinin incelenmesi ve Türkiye'nin güvenliğine etkileri sempozyumu), 27 May 2007, accessed at http://www.tsk.mil.tr/10_ARSIV/10_1_Basin_Yayin_Faaliyetleri/10_1_7_Konusmalar/2004/ sempozyum_acis_konusmasi_240504.html, 25 December 2008; Chief of General Staff General Yaşar Büyükanıt's speech at the Military Academy, 2 October 2006, accessed at http://www.tsk.mil.tr/ 10_ARSIV/10_1_Basin_Yayin_Faaliyetleri/10_1_7_Konusmalar/2006/harpakademilerikonusmasi_ 02102006.html, 23 December 2008.

${ }^{60}$ Robert Keohane, Power and Governance in a Partially Globalized World (New York: Routledge, 2002), 75 .

${ }^{61}$ Lenore Martin, “Turkey's National Security in the Middle East," Turkish Studies 1 (Spring 2000): 83-106.

${ }^{62}$ Kirişci, "Between Europe and the Middle East. 
of liberal democratic transformation to be welcomed in the region, Turkey's own performance at home would need to demonstrate that Islam, secularism, and liberal democracy could go together. In this sense, the AKP leadership appears to have believed that the continuation of the EU accession process and Turkey's adoption of EU foreign policy norms in the region would help improve Turkey's regional standing.

Noteworthy in this regard is that unless Turkey succeeded in resolving its perennial Kurdish problem at home, the growing Kurdish nationalism in Iraq would augur badly for Turkey's territorial and societal security. The picture is very clear: for Turkish citizens of Kurdish origin to remain loyal to Ankara, and not attracted to northern Iraq, Turkey's placement in the EU accession process is a must. That is the most credible way to secure Ankara's power of attraction in the eyes of Turkey's Kurds. The continuation of the Europeanization process implies that resolution of the Kurdish dispute through political means is possible. It is within this context that several reform packages have recently been released that included significant changes regarding the Kurdish language and culture as well as political rights. The equation is straightforward: The more the political arena is opened for Kurdish groups to express their grievances, the less support the PKK receives from the public. The resolution of PKK terrorism and the wider Kurdish problem has now become more urgent than ever. As Osman Öcalan, the brother of the PKK leader Abdullah Öcalan, bluntly put it, state repression was a precondition for the popular support that the PKK and its military uprising found among the Kurds. "We have to thank Turkey. We won half of the town of Cizre by our own efforts, the other half has been presented to us on a silver plate." ${ }^{.3}$

However, this particular outcome can also be explained by the emerging dynamics of the security situation in northern Iraq. In an environment in which the Kurds of northern Iraq have gained quasi-independence status, the outcome of Turkey's struggle against the PKK-led ethnic separatist terrorism has become more vital than ever. That said, the change of course from the realist exclusionist to liberal integrationist approach toward the Kurds of northern Iraq appears to have been motivated by Ankara's concern that the Kurdish-origin citizens of Turkey's Kurds still feel themselves loyal to Ankara rather than being attracted to northern Iraq. It also appears that the war against the PKK cannot be won decisively without securing the cooperation of the Iraqi Kurdish groups. ${ }^{64}$ The dynamics of the EU accession process would not suffice to understand the logic of such recent changes in Turkey's approach to Iraqi Kurds.

Similarly, the possibility of Iraq's dismemberment and the emergence of an independent Kurdish state can only be avoided through increasing regional

\footnotetext{
${ }^{63}$ Hamit Bozarslan, "Human Rights and the Kurdish Issue in Turkey: 1984-1999," Human Rights Review 3 (October-December 2001): 45-54.

${ }^{64}$ Bill Park, "Iraqi Futures, Turkish Options," European Security 17 (March 2008): 85-104.
} 
cooperation and forming closer relations with Iraqi Kurds in line with the EU's foreign policy norms. Reflecting this mentality, Turkey has lately adopted a liberal-integrationist approach toward the Iraqi Kurds, the prime goal of which is to help integrate this region into the Turkish economy by increasing the volume of trade and Turkish investments in the region. ${ }^{65}$ The view that Iraqi Kurds are Turks' relatives, rather than potential enemies, has gradually gained ground in Ankara. Plus, such an approach would also help improve Turkey's crisis-laden relations with the United States. Any military campaign against PKK strongholds in northern Iraq or containment of Iraqi Kurds through military means would have jeopardized Turkey's relations with the United States, particularly when the United States valued stability in northern Iraq and viewed the Iraqi Kurdish groups as allies.

\section{Realpolitik Concerns to Contain the Rising Iranian Influence in the Region}

The apparent Europeanization in Turkish foreign policy in recent years has also been informed by the realpolitik consideration to counterbalance the rising Iranian influence in the Middle East following the regime change in Iraq. Despite the fact that Ankara and Tehran continue to share a cooperative relationship based on increasing economic interactions, Ankara has equally grown alarmed by Tehran's increasing influence in post-Saddam Iraq. Ankara has two main concerns. The first pertains to the differences between the Turkish and Iranian models of state-religion relationship. To Ankara, strengthening Turkey's secular-liberal Islam is what is needed to prevent Iran's theocratic Islamic model from becoming dominant in the region. ${ }^{66}$ This is not only in the interest of Turkey but also of the larger Western international community in the post-September 11 era. What is critical in this regard is that for the secularliberal version of Islam to be perceived as more legitimate than the Iranian version of Islam, the former needs to produce concrete benefits for the well-being of the Turkish people. More importantly, it needs to be proven that Islam is not an obstacle to liberal democracy and free-market-oriented economic development. In this sense, Turkish policymakers see the continuation of the accession process and eventual membership in the EU as vital for the success of the Turkish model. A Turkey that becomes estranged from the European Union might possibly lose the ideological battle against Tehran.

Second, if Iran goes nuclear and tries to export its regime to other places in the region, this will certainly be against Turkey's security interests. Ankara

\footnotetext{
${ }^{65}$ Tarık Oğuzlu, "Middle Easternization of Turkey's Foreign Policy: Does Turkey Dissociate from the West?" Turkish Studies 9 (March 2008): 3-20, at 18.

${ }^{66}$ Patrick F. Gillis, "U.S. Turkish Relations: The Road to Improving a Troubled Strategic Partnership," USAWC Strategy Research Project Report, U.S. Army War College Carlisle Barracks, Pennsylvania (2004), accessed at http://www.dtic.mil/cgi-bin/GetTRDoc?Location $=$ U2\&doc= GetTRDoc.pdf\&AD=ADA424313.
} 
does not want to channel its limited resources into getting nuclear weapons as well as find itself in the midst of an armed confrontation between the West and Iran. The continuation of the EU accession process and Turkey's adoption of EU foreign policy norms in the Middle East would not only help Ankara stem the tide of growing Iranian influence but would also lead the Iranian regime not to suspect Turkey's long-term intentions in the region. If the prospects of Turkey's accession to the EU dwindled and Ankara pursued nationalist and unilateral policies in the region, Tehran would probably interpret such Turkish moves as threatening. On the other hand, supporting U.S.-led coercive strategies toward Iran would harm Turkey's interests, for not only would Tehran view such a Turkey as threatening, but also Turkey's growing soft power in the region would be tainted.

\section{CONCLUSION}

This research has tried to demonstrate that Turkish foreign policy in recent years appears European. It has been argued, however, that this change has far more to do with realpolitik security considerations and the AKP's coming to power than with the dynamics of the EU accession process and Turkey's strong ideational commitment to EU membership. The desire to counterbalance the United States and Iran in the post-September 11 era, to mitigate the negative consequences of the growing instability in the Middle East on security interests at home, and the AKP's efforts to help increase its domestic legitimacy and realize the so-called neo-Ottomanist foreign policy vision appear to have all brought Turkey closer to the European Union. Such a development has become possible despite the growing Euro-skepticism over the recent years. Not only the traditional security elites but also AKP circles have gradually adopted a critical stance on the dynamics of the EU accession process. The ideational commitment on the part of these circles to EU membership has radically eroded.

Therefore, this research has argued that it would be more appropriate to define the recent changes in Turkey's foreign policy in EU fashion as an example of Turkey's Europeanizing foreign policy, i.e., apparent Europeanization. It is certain that Turkey has come closer to the EU's foreign policy understanding in terms of style, process, and outcome, yet such changes would probably have occurred had Turkey not been pursuing membership in the EU. Turkey has gradually come to view membership in the European Union as the shortest way to escape the danger of being drawn into the Hobbesian security environment in the Middle East. And it seems that this process will continue in the years to come, irrespective of the degree of Turkey's ideational commitment to EU membership, the degree of the EU's commitment to Turkey's accession, and the composition of the Turkish government. 